\title{
STUDY OF FACTORS AFFECTING THE ATTITUDE OF DEBT FINANCING DECISION
}

\author{
Satoto Shinta Heru*, Nilmawati, Nurrohim K.P. Hasa \\ Department of Management, Faculty of Economics and Business, \\ National Development University, Indonesia \\ `E-mail: shintaherusatoto@gmail.com
}

\begin{abstract}
This study aims to examine the influence of the variables of economic goal orientation, experience with creditors, financial knowledge, and family control to explain financial attitudes related to debt financing decisions with family commitment as a moderating variable and age and size of the company as control variables. The respondents in this study consisted of 123 owners or managers of small and medium businesses in the Sleman Regency of Yogyakarta. The test results show that the orientation of economic goals, experience with creditors, financial knowledge, and family control have a positive and significant influence on attitudes related to debt financing decisions. This research also proves that the moderating variable of family commitment can strengthen the positive effect of family control on managers' attitudes in debt financing decisions.
\end{abstract}

\section{KEY WORDS}

Orientation of economic goals, positive experience with creditors, financial knowledge, need for control, family commitment.

Financial decision making related to funding sources, such as the choice between sources of debt or equity funding, is an important thing for a company. This will be very felt in the family company. In family companies, where the existence of family control is very dominant, the company's decision is a policy of the owner or manager who may not be able to meet the optimal funding options for some shareholders. Because the decision to choose the source of funds for family companies is often not only based on economic motives but also influenced by non-economic values such as socio-cultural and family influence.

A family company is a company that has unique characteristics, where the family plays a large role in managing the company. Family involvement in the ownership and management of companies and workers who are mostly family members need to be taken into consideration in making a decision related to the company. In non-public companies, especially small and medium-sized companies, where almost all are privately or familyowned, the task of making financial decisions, such as financing decisions, are strongly influenced by the attitude of the owner as manager (Heck, 2004; Van Auken, 2005). This attitude later is one of the key factors to explain the behavior of making future decisions. In this case, the decision to finance a family company is highly influenced by the personal characteristics of the owner-manager, such as individual attitudes (Carter and Van Auken, 2008), and economic and non-economic motivations (Chrisman, Chua, and Litz, 2004). Attitudes are established through economic and non-economic beliefs held by decisionmakers about the outcomes of certain behaviors and are therefore a key factor in the personal decision-making process (Ajzen 1991).

Several studies have shown evidence that family firms prefer the use of internal funds and funds from the family rather than the use of debt (McConaughy, et.al., 2001; Romano, Tanewski, and Smyrnios, 2011). This is because the family company owner refuses to use external funds and forgets growth opportunities so as not to jeopardize the company's condition. However, Balco-Mazagatos, de Quevedo-Puente and Castrillo (2007), Coleman and Carsky, (1999), and Wu, et.al (2007) research shows that the use of debt as a source of funds in a family company is no different than that of a company in general. The difference in the decision to use the source of funds is usually due to the family company; decision making is highly dependent on the manager who is also the owner of the company (Feltham, 
Feltham, and Barnett, 2005). The financial attitude in the family business may be the result of the personal attitude of the owner-manager. Therefore, family businesses are often bound to financial logic that is not only based on economic motivation but also personal preferences regarding growth, risk, and ownership control (Gallo, et., Al., 2004).

Chrisman, Chua, and Litz (2004) found that in terms of financial decision making, family-owned companies are very likely to follow financial logic that is driven by economic motives such as company growth and non-economic motives such as socio-emotional value. Croci, Doukas, and Gonenc (2011) prove that in family companies, family control plays an important role in decision making regarding the use of debt. In family businesses, funding policies are influenced by motives for control. Family-controlled companies prefer funding using debt compared to sources of funds from equity. This is because the family company is committed to having fewer capital resources than public companies to avoid conflicts that arise within the company. While Koropp, Grichnik, and Kellermanns (2013) show that a manager who has a high economic orientation, will tend to increase profits and continue to develop the business. This manager will prioritize the use of external financial resources. Compared to managers who prefer to maintain the personal emotional value of a business and tend to forget growth opportunities that cannot be funded by internal funds (Mahérault, 2004)

Gallo, Tapies, and Cappuyns (2004), and (Romano, Tanewski, and Smyrnios 2001) prove the influence of knowledge finance towards financial decision making. Financial knowledge includes knowledge of available financial sources, functioning of the capital market, financial contracts, cash flow management practices, cash management systems, and so on. Good financial knowledge, coupled with expertise in a variety of existing debt products with suitable credit conditions for family businesses, will reduce the company's dependence on traditional financial sources, such as internal funds. Korrop (2013) shows that a positive experience with creditors is also an important determinant of attitudes related to debt use decisions. Previous experience related to the selection of external funding sources and the attitudes or behavior of fund or loan providers tends to determine beliefs about the attitudes and behavior of loan providers in the future, which in turn will shape the attitude of the owner or manager in choosing the provider of funds. Owners or managers who have previous unpleasant experience in obtaining debt will be more careful in making decisions to add debt. Therefore, direct personal experience experienced by the owner or manager of the provider of funds is more likely to influence attitudes in decision making regarding the use of debt.

Besides, high family commitment will strengthen the influence of family control on debtrelated attitudes. In this case, high family commitment will make business owners have strong support in using the source of funds from debt with various risks that may occur. If high family commitment coincides with a negative experience with a creditor that happened before, then a negative attitude towards debt is likely to become more apparent. Conversely, if family commitment is low because financial considerations are more dominant, then negative experiences with creditors will not greatly affect attitudes towards debt. Koropp, at.al. (2013) proved that family commitments moderate relations of economic orientation, positive experience with, and knowledge of creditors financial attitudes managers.

This study aims to reexamine the research conducted by Koropp, et.al (2013), which examines the influence of economic goal orientation variables, experience with debt suppliers (creditors) and financial knowledge of managers, on financial attitudes in debt financing decision making, with family commitment as a moderating variable. This study adds a family control variable to explain attitudes in debt financing, with the consideration that small and medium-sized companies whose ownership is mostly family-owned tend to retain their ownership and avoid others from interfering in management, so it is suspected this variable is thought to influence the attitudes of managers concerning debt funding.

This research takes place in the Sleman Regency of Yogyakarta with the consideration that the largest number of small and medium enterprises in this area is compared to other regions or districts in Yogyakarta. The largest number of UKM in Yogyakarta Province is in Sleman Regency with $33.64 \%$ followed by Bantul Regency with $24.52 \%$, Gunung Kidul 
Regency with $14.90 \%$, Yogyakarta City with $12.29 \%$, and finally Kulon Progo Regency with 7, 65\%. Whereas the ownership of Sleman Regency financial reports also had the highest percentage of ownership, namely $13.97 \%$, followed by Yogyakarta City $13.93 \%$, then Bantul Regency at $7.22 \%$, Kulon Progo Regency at $6.79 \%$, and finally Gunung Regency. Kidul as much as $4.60 \%$. Besides, data on ownership of financial statements from the total listed companies in Sleman Regency also has the highest level compared to other regions or districts.

\section{LITERATURE REVIEW AND HYPOTHESIS DEVELOPMENT}

Research Romano, Tarnowski, and Smyrnios (2001) show that the economic goals of the owner of a family company are positively related to debt acquisition. Thus, a higher level of economic orientation positively influences the owner-manager financial attitude towards debt. Managers who own family companies may exhibit high economic goal orientation regarding business-related dimensions and at the same time show high social (noneconomic) orientation in terms of family dimensions. The owner-manager of the family company will facilitate collaborative thinking when family commitments are high. Thus, if pursuing economic goals is paired with a low level of family commitment to business, a positive attitude towards debt tends to be unmitigated. Owner managers tend to like and develop maximum strategies to maximize profits and risky growth, facilitated by the use of debt financing (Koropp, et.al, 2013).

Hypothesis 1: The orientation of economic goals has a positive effect on the attitude of managers in debt financing.

According to Michaelas, Chittenden, and Poutziouris (1998), owners or managers who have unpleasant past experiences are more likely to delay growth opportunities that require new debt problems. Conversely, owners of family companies with favorable previous experience with debt financing are not careful enough to increase additional debt (Michaelas, Chittenden, and Poutziouris 1998). According to Gudmundson, Tower, and Hartman (2001), family companies that rarely use formal data collection techniques and processes by gathering secondary information, will prioritize collecting data from personal experience directly in the decision-making process. Organizational decision-makers prefer direct experience knowledge because it has a richer meaning, and facilitates understanding (Argote 1999). Therefore, it is possible that positive experiences with debt suppliers positively influence the attitude of the owner-manager of the family company towards debt. From this description, the hypothesis proposed is:

Hypothesis 2: experience with creditors has a positive effect on the attitude of managers in debt financing.

Michaelas, Chittenden, and Poutziouris (1998) show that the owner/manager's decision to use debt is influenced by his knowledge of available financial sources. A more knowledgeable owner is generally more likely to use foreign debt financing, which reflects a better attitude towards debt. From this description, the proposed hypothesis is: financing.

Hypothesis 3: financial knowledge has a positive effect on managers' attitudes in debt

Neubauer and Lank (1998) state that factors of business ownership, independence, and family control influence owner financing decisions (Dreux 1990). Dailey, Ruschling, and De Mong (1977), Hutchinson (1995), and Shrivastava and Grant (1985) suggest that entrepreneurs who have strong preferences tend to use equity or retained earnings as financial sources. According to Kotkin (1984), the use of venture capital as a source of capital raises concerns about losing control. Hutchinson (1995) also shows that ownermanagers who have a strong desire to maintain corporate control can actively place limits on the use and growth of equity. This view is supported by Berger and Udell (1998), Harvey and Evans (1995), and Barton (1989), who find that issues relating to risk control and avoidance affect capital structure and financing decisions.

In China and many other developing countries, a weak institutional environment heightens agency problems and causes greater distrust between owner-managers and 
external capital providers (Young et al., 2008). Previous studies have shown that SMEs in China are generally reluctant to seek external funding because of their distrust outside their immediate family and social networks (Pukthuanthong and Walker, 2007). Borgia and Newman (2012) show that the capital structure of SMEs in China is mainly influenced by an aversion to external controls and a tendency to take risks. Meanwhile, research conducted on SMEs in Western countries shows that some owners/managers prefer to rely on internal funding sources, for fear of reliance on external sources can cause loss of control over the company and limit the power of owners to make decisions independently from investors ( Berger and Udell, 1998; Harvey and Evans, 1995; Hutchinson, 1995). So, in general, it can be concluded that the need to control the company by the owner (manager) will negatively affect his financial attitude regarding funding with debt. From this description the proposed hypothesis is:

Hypothesis 4: the need for control has a negative effect on managers' attitudes in debt financing.

One part of the family culture is family commitment. Family commitment is an important factor that influences business (Klein, Astrachan, and Smyrnios, 2005) and is related to financial performance (Van Auken and Werbel, 2006). The commitment element is closely related to the company's identification (Zahra et al, 2008) which is a form of psychological involvement. High family commitment can lead to positive attitudes of family members towards the company. Thus, family commitments tend to increase interest and active participation in business. Therefore a higher family commitment can lead to increased social interaction between the family and the manager of the family company owner which influences the decision making related to the company.

According to Koropp, et.al (2013), because personal characteristics affect the formation of commitments and are not always uniform in all family companies, personal characteristics have a moderate influence on the formation of individual financial choices. Their results show the influence of financial knowledge, positive experience with debt suppliers, and orientation of economic goals on the formation of managerial attitudes (debt decisions) moderated by the level of family commitment to the business.

When family commitments are higher, the positive attitude of funding with debt is likely to be reduced by the desire to not only create economic wealth but also socio-emotional wealth, family work, or management control in the family. A higher level of commitment associated with a desire to be free to do business in the organization (Davis, Allen, and Haye, 2010; Zahra et al, 2008), will reduce attitudes toward debt, because lower debt allows for stronger family control in the family. future (McConaughy, Matthews, and Fialko 2001). From this description, the hypothesis put forward is

Hypothesis 5: High family commitment to business weakens the positive influence of economic goal orientation on managers' attitudes in debt financing.

If the family is very committed to business, the willingness to protect the family business as a source of socio-emotional wealth is likely to replace the direction of the performance of the family company (Gómez-Mejía et al 2007). In this case, the owner will try to protect the company and limit the most involvement from outside to fully maintain control for future generations, even for sustainable growth and other opportunities (Mishra and McConaughy, 1999). So, if a high level of family commitment to the business is followed by previous negative experiences with debt suppliers, a negative attitude towards debt is likely to be more pronounced. However, if family commitments are low, financial considerations are likely to occur and negative experiences with debt suppliers will not greatly influence attitudes towards debt. Alternative sources of funding (such as family funds) tend not to be available or considered as desired alternatives, and lenders may not be considered as impediments to family and wealth control.

Hypothesis 6: High family commitment has the positive effect of positive experiences with creditors on managers' attitudes in debt financing.

Family commitment will affect the owner-manager ability to apply financial knowledge because sound financial decision making will be affected by an emphasis on non-goal oriented goals. In particular, a family commitment to business can weaken the positive effect 
of owner-manager financial knowledge about attitudes in debt financing, because it causes cognitive biases in business decisions and concerns endanger family wealth, control, and ownership information that will reduce rational information behavior (Gómez-Mejía et al, 2007). From this description, the proposed hypothesis is:

Hypothesis 7: High family commitment weakens the positive influence of financial knowledge on managers' attitudes in debt financing.

High commitment will lead to a strong need to continue to be able to control and protect the family business, protect the interference of others in managing the company's finances. So that high commitment will strengthen the negative influence of the need to control the company towards managers' attitudes related to debt financing.

Hypothesis 8: High family commitment to the business reinforces the negative influence of the owner (manager) control on the attitude of the owner (manager) regarding debt.

\section{THEORETICAL FRAMEWORK}

Due to the importance of attitudes in shaping behavior, this study emphasizes aspects that influence the owner-manager attitude such as manager's financial knowledge, experience of debt suppliers (creditors), orientation of economic goals, and the need for family control that influences financial attitude of the owner/manager of the company in debt financing. Also, family commitment is included as a moderating variable with the consideration that the element of commitment is closely related to the personal identification of the company (Zahra et al, 2008), which is a form of psychological involvement. The theoretical framework of thought based on the description is shown in Figure 1.

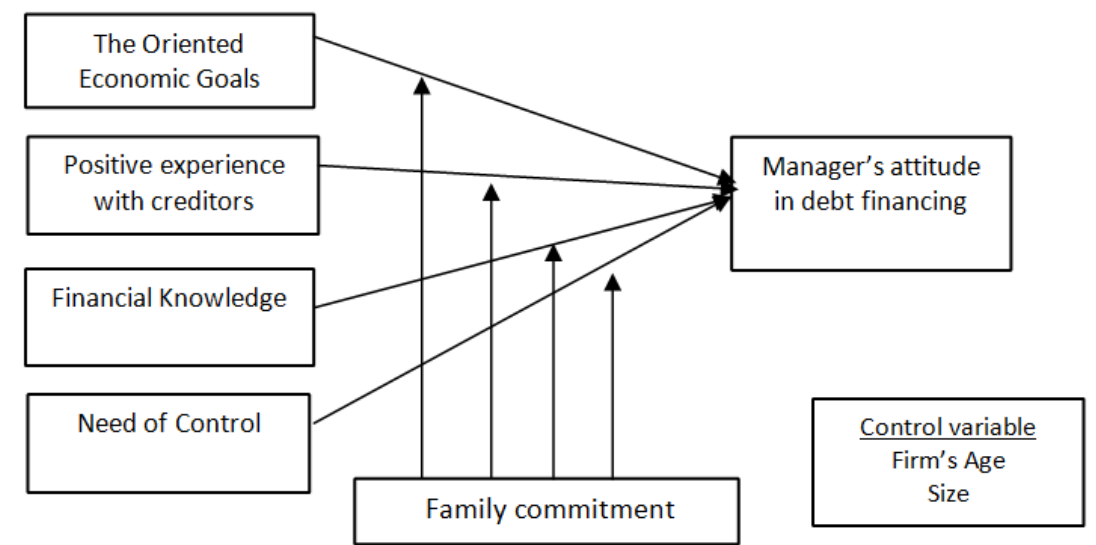

Figure 1 - Relationship Model of Economic Goals Orientation, Positive Experience with Creditors, Financial Knowledge, Need for Control, and Manager's Attitudes in Debt Financing moderated by Family Commitments

\section{METHODS OF RESEARCH}

The population in this study was all small and medium businesses in the Sleman Regency of Yogyakarta. Sampling was done using a method of non-random sampling, namely convenience sampling. From the results of the distribution of questionnaires as many as 123 respondents were collected.

The dependent variable in this study is the attitude of managers in funding decisions. Individual attitudes are generally judged by perceptual items related to overall likes or dislikes, such as good-bad, dangerous-useful, pleasant-unpleasant, or likable-not (Ajzen 2001). In this study, the owner-managers financial attitude towards debt is assessed by four things, namely evaluative words: good, useful, useful, and wise.

The independent variable used consists of four variables namely orientation of economic goals, positive experience with creditors, financial experience, and the need for 
control. To explain the economic goal orientation variable 3 indicators are used, namely: maximizing the value of the company's owner, minimizing capital costs, and maximizing business profits. (Button, Mathieu, and Zajac 1996).

Indicators used to explain positive experiences with creditors are positive experiences with banks in the past, and positive experiences with other creditors in the past. For the variable size of financial knowledge, indicators are used: company investment financing options, investment financing options for a particular company, and choice of financing sources for new plant acquisitions. Variables need for company control are measured using indicators:

Shareholders' permission from non-families, ownership opportunities (shares) for nonfamilies, and the benefits of external funding sources for the company.

This study also uses moderation variables, namely family commitment. The measurement of family commitment (Family Commitment) is done by using four items that reflect commitment to the family, loyalty to the family business, and pride in the business. For all variables used managers are asked to indicate the extent of their agreement $(1=$ strongly disagree to $5=$ strongly agree). The four-item averages will then be averaged. This study also included control variables namely the age and size of the company. The age of the company is calculated from the natural logarithm since the year the company was founded (Lopez-Gracia and Sanchez-Andujar, 2007). While the size of the company is measured by the average turnover obtained by the company per month.

To examine the effect of orientation on economic goals, experience with creditors, financial knowledge and the need for control over the attitude of managers in debt financing, the following regression equation will be used:

1. The main equation (without moderation):

Attitude $=\alpha_{0}+\alpha_{1}$ Economic Orientation $+\alpha_{2}$ Financial Experience $+\alpha_{3}$ Financial Knowledge $+\alpha_{4}$ Need for Control $+\alpha_{5}$ Family Commitment $+\alpha_{6}$ Age $+\alpha_{7}$ Size $+\varepsilon$ model (1)

2. Moderation Equation:

Attitude $=\gamma_{0}+\gamma_{1}$ Economic Orientation $+\gamma_{2}$ Financial Experience $+\gamma_{3}$ Financial Knowledge $+\gamma_{4}$ Need for Control + $\gamma_{5}$ Family Commitment $+\gamma_{6}$ EconomicOrientation*Family Commitment $+\gamma_{7}$ FinancialExperiences * Family

Commitment $+{ }_{\gamma_{8}}$ FinancialKnowledge * Family Commitment $+{ }_{\gamma_{9}}$ NeedforControl ${ }^{*}$ Family Commitment $+\alpha_{10}$ Age + $\alpha_{11}$ Model + Family model (2)

\section{RESULTS OF STUDY}

The results of testing the main variables with the company's age control variables are shown in the following table:

Table 1 - Regression Analysis Results with Variable Control (Age and Firm Size)

\begin{tabular}{|c|c|c|c|c|c|c|}
\hline \multirow{2}{*}{ Variable } & \multicolumn{3}{|c|}{ Model 1 } & \multicolumn{3}{c|}{ Model 2 } \\
\cline { 2 - 7 } & $\begin{array}{c}\text { Unstandardized } \\
\text { Coefficient }\end{array}$ & $\mathrm{t}$ & Sign & $\begin{array}{c}\text { Unstandardized } \\
\text { Coefficient }\end{array}$ & $\mathrm{T}$ & Sign \\
\hline (Constant) & $-2,202$ & $-1,599$ &, 113 & $-11,686$ & $-2,707$ &, 008 \\
\hline Eco_Orientation &, 316 & 2,712 &, $008^{* *}$ &, 251 & 2,149 &, $034^{*}$ \\
\hline Experience &, 394 & 3.132, & 002 & ${ }^{*}, 692$, & & 940,349 \\
\hline Science, & 368 & 2,809, & 006 & ${ }^{* *}, 837$ &,- & 003,998 \\
\hline controls, & 554 & 3.222, & $001^{*}$ &,- 002 & 2,985, & $003^{*}$ \\
\hline commitment &,- 325 & -2.690, & $008^{* *}$ & 3,015 & 2,026 &, $045^{*}$ \\
\hline Company age &, 011 &, 727 &, 469 & 2,155 &, 915 &, 362 \\
\hline Company size &, 024 &, 346 &, 730 &, 011 &, 157 &, 876 \\
\hline Eco_orientation ${ }^{*}$ commitment & & & &,- 093 &,- 546 &, 586 \\
\hline Experience ${ }^{*}$ commitment & & & &, 102 &, 672 &, 503 \\
\hline Knowledge*commitments & & & &,- 602 & -2.535 & $013^{*}$ \\
\hline Control ${ }^{*}$ commitment, & & & & -11.686 & -2.707 & 008 \\
\hline
\end{tabular}

Description: * significant at $\alpha=5 \%,{ }^{* *}$ significant at $\alpha=10 \%$. 
The test results show that the model 1 , coefficient of regression experience with creditors of 0.394 (sign $=0.002$ ), and the coefficient of need for control of 0.554 (sign = 0.001 ) has a significance level $<0.05$, while the regression coefficient of economic orientation variables is 0.316 (sign $=0.008$ ) and financial knowledge regression coefficient of 0.280 (sign $=0.006$ ) have a significance level $<0.10$ which means that economic orientation variables, experience with creditors, financial knowledge, and the need for control influence the decision making attitude related to debt. For the family commitment variable, the test results show that the regression coefficient of the family commitment variable is -0.325 with a significance level of 0.005 (significant at $\alpha=0.10$ ). This shows that the family commitment variable has a negative and significant influence on the attitude of decision making related to debt. So it can be concluded that hypotheses 1,2,3 and 4 are supported.

In testing model 2, the test results show that the economic orientation variable regression coefficient is 0.251 ( $\operatorname{sign}=0.034$ ), the need for control coefficient is -0.002 ( $\operatorname{sign}=$ 0.003 ), and the family commitment variable regression coefficient is 3.015 ( $\operatorname{sign}=0.045$ ), has a significance level $<0.05$ which means that the economic orientation variable, the need for control and family commitment significantly influence the decision-making attitude related to debt. To test the influence of the family commitment variable as a moderating variable shows that the regression coefficient of experience with creditors * family commitment of -0.093 (sign $=0.586)$, financial regression coefficient * family commitment of $0.102(\operatorname{sign}=0.503)$, and the regression coefficient of the need for control * family commitments of -0.602 (sign = 0.013). This means that the family commitment variable is only able to moderate the influence of the family control variable on the debt decision attitude and is not able to moderate the influence of the financial knowledge variable, and the need for control over the decision making attitude regarding debt. While the results of data processing the effect of moderating variables on the relationship of economic orientation variables to the attitude of debt shows the exclusion of this variable from the regression equation. The results of this study indicate that family commitment variables can moderate the relationship between family control and debt-related attitudes. So it can be concluded that hypothesis 8 is supported.

\section{DISCUSSION OF RESULTS}

Testing the influence of orientation on economic goals, experience with creditors, financial knowledge, the need for control, and family commitment to the attitude of decisions related to debt shows that economic orientation, experience with creditors, financial knowledge and family control has a positive and significant effect on attitudes related to debt in small and medium-sized companies. The orientation of economic goals has a positive influence on attitudes related to debt decisions. In general, a company must have an economic goal orientation which is to obtain profits from the results of its business. The high level of economic goal orientation will affect managers' financial attitudes regarding the use of debt. In small and medium-sized companies, the need for funding sources is often a significant problem because of the limitations they have. Thus, the higher the orientation of the economic goals set, the higher the manager's tendency to use debt as a source of funding. According to Anderson, Mansi, and Reeb (2003), the decision to use debt in small and medium-sized companies is also supported by lower debt costs for companies that are family-owned. This is also in line with the pecking order theory which assumes that economic motives will influence funding decisions. Pecking order theory focuses on the low tendency to use retained earnings as a source of funding compared to debt. According to Michielss and Molly (2017), this concept is suitable for use in family companies, where the attitude of funding in a family company is not only based on financial motives, but also takes into account non-economic considerations such as risk-taking tendencies, emotions, preferred values, and family goals.

The positive effect of experience with creditors on the attitude of decisions related to debt shows that a person who has a pleasant experience with a creditor will meet his funding needs by increasing debt when the source of internal funds is not able to meet the needs of 
funds. In this case, the experience with the creditor owned will be used by the business owner to improve debt-related decision making. Business owners will be more careful in choosing creditors based on the experience they have, and creditors who provide good experience will tend to be the choice when the company needs additional funds. This experience becomes important for business owners in improving their skills and knowledge, which in turn will improve funding decision-making (Bradley, Hirad, Perry, and Zorn, 2001; Weiner, Baron-Donovan, Gross, and Block-Leib, 2005; Johnson and Sherraden, 2007; Mandell, 2008). According to Lyions et al. (2002), financial experience will influence someone in making credit decisions. Whereas Borden, Lee, Serido, and Collins (2008), Robb and Sharpe (2009), and Lachance, Beaudoin, and Robittaille (2006) prove that the more a person's financial experience will be associated with a person's high debt. High financial experience will reduce the fear of using credit, which leads to high use of debt.

Financial knowledge has a positive influence on managers' attitudes regarding debt decisions. Family companies that have managers who have good financial knowledge will be more careful in taking financial attitudes related to debt. Adequate financial knowledge related to sources of funding, making managers will be able to consider the best decisions regarding funding sources. Financial knowledge will make a manager have enough information and be able to make effective decisions from all financial sources they have. In a family company, equity plays a very important role in the survival of the company. With good financial knowledge, managers will be able to consider whether funding sources can be fulfilled by using equity or should use external funding sources. Shleifer and Vishny (1997) explain that in a family company where most or even all shareholders and leaders are family members, information about investment opportunities and future cash flows that they have will be better than information owned by investors. Consequently, equity is very important in a company's capital structure and is more sensitive to possible changes in information than debt. This causes the cost of equity will be higher than the cost of debt to the family company and causes equity to be less attractive than debt as a source of funding.

The need for control has a positive influence on managers' attitudes regarding debt. Companies that are owned by families can have stronger control in making decisions regarding debt than companies that are owned by the public. In this case, family-owned companies generally have the same interests to be able to prosper the family. Thus, conflicts of interest that arise will be smaller compared to companies owned by the public. This is in line with Anderson's (2013) study which found that family-owned companies would prefer low-cost debt funding because they have a low conflict of interest. According to Demsetz and Lehn (1985), companies that have good family control do not like high-risk financial funding decisions that will eliminate their power such as using large equity in meeting funding needs. Consequently, family businesses tend to use debt rather than equity in meeting their sources of funds.

Regarding the influence of moderating variables, the results of the study indicate that family commitment mediates the influence of family control with debt-related attitudes. This shows that the existence of family commitment will strengthen the negative influence of family control on debt-related attitudes. According to Braunstein and Welch (2002), increasing financial knowledge and financial experience does not always guarantee changes in attitudes related to debt decision making. Changes in attitude related to the decision to take debt, certainly influenced by other variables in this case influenced by family commitment. Families who are committed to the business will try to protect their businesses and limit external involvement to be able to sustain the company for the next generation. A high level of family commitment to the business followed by good family control will strengthen attitudes related to the use of debt. Or in other words, lenders are not considered as obstacles to the control of family and wealth.

\section{CONCLUSION}

The orientation of economic goals, financial knowledge, positive experiences with creditors and family control are important determinants of attitudes related to debt use 
decisions. For small and medium-sized companies that have a high economic goal orientation, managers will tend to decide to choose debt in meeting their funding needs. In this case, the attitude related to debt decisions is based on financial knowledge and experience that has been previously owned. Experiences that have been experienced previously related to the selection of external funding sources and the attitudes or behavior of fund or loan providers, tend to determine beliefs about the attitudes and behavior of loan providers in the future, which in turn will shape the attitude of the owner or manager in choosing the provider of funds (Korropp et al, 2013). Owners or managers who have previous unpleasant experience in obtaining debt will be more careful in making decisions to add debt. Therefore, direct personal experience experienced by the owner or manager of the provider of funds is more likely to influence attitudes in decision making regarding the use of debt.

Besides, family control and high commitment will strengthen the influence of positive experiences with creditors on debt-related attitudes. In this case, family control and high commitment will make business owners have strong support in using the source of funds from debt with various risks that may occur. If high family commitment coincides with a negative experience with a creditor that happened before, then a negative attitude towards debt is likely to become more apparent. Conversely, if family commitment is low because financial considerations are more dominant, then negative experiences with creditors will not greatly affect attitudes towards debt.

\section{REFERENCES}

1. Ajzen 1991, The Theory of Planned Behavior, Organizational Behavior and Human Decision, Processes, 50(2), 179-211.

2. Anderson, RC, and Reeb, D., M., 2003, Founding-Family Ownership, Corporate Diversification, and Firm Leverage, Journal of Law \& Economics, 68, 263-285.

3. Anderson, RC, Mansi, SA, and Reeb, D., M., 2003, Founding-Family Ownership and the Agency Cost of Debt, Journal of Financial Economics, 68(2), 263-285.

4. Argote 1999, Organizational Learning: Creating, Retaining, and Transferring Knowledge. Norwell, MA: Kluwer.

5. Arsov, S, and Naumoski A, 2016, Determinants of Capital Structure: An Empirical Study of Companies from Selected Post-Transition Economies, Journal of Economics and Business, Vol. 34, No. 1, 2016, 119-146.

6. Balios, DN, Daskalakis, N, Eriotis, and Vasiliou, 2016, SMEes Capital Structure Determinants During Severe Economics Crisis: The Case of Greece, Cogent Economics \& Finance, Volume 4, Issue 1.

7. Bandyopadhyay, A, and Nandita Malini A, B, 2016, Factors determining capital structure and corporate performance in India: Studying the business cycle effects, The Quarterly Review of Economics and Finance, Volume 61, Pages 160-172.

8. Barton, 1989, Small Firm Financing: Implications from a Strategic Management Perspective, Journal of Small Business Management 27(1), 1-7.

9. Basco and Perez Rodriguez, 2009, Studying the Family Enterprise Holistically: Evidence for Integrated Family and Business Systems," Family Business Review 22(1), 82-95.

10. Berger and Udell, 1998; The economics of small business finance: The roles of private equity and debt markets in the financial growth cycle. Journal of Banking \& Finance 22:613-673.

11. Berghoff, 2006, The End of Family Business? The Middle stand and German Capitalism in Transition, 1949-2000, Business History Review 80(2), 263-295.

12. Blanco-Mazagatos, de Quevedo-Puente, and Castrillo, 2007, The Trade-Off between Financial Resources and Agency Costs in the Family Business: An Exploratory Study, Family Business Review 20(3), 199-213.

13. Borden, L., M., Lee, S., A., Serido, J., and Collins, D., 2008, Changing College Students' Financial Knowledge, Attitudes and Behavior through Seminar participation, Journal of Family Economic Issues, 29(1), 23-40. 
14. Borgia, D., and Newman, A., 2012, The Influence Of Managerial Factors On The Capital Structure Of Small And Medium-Sized Enterprises In Emerging Economies Evidence From China, Journal of Chinese Entrepreneurship, Vol. 4 No. 3, 180-205.

15. Carter and Van Auken, 2008, Capital Acquisition Attitudes: Gender and Experience," Journal of Entrepreneurial Finance and Business Ventures 12(2), 55-73.

16. Chrisman, Chua, and Litz, 2004, Comparing the Agency Costs of Family and Non-Family Firms: Conceptual Issues and Exploratory Evidence, Entrepreneurship: Theory and Practice 28(4), 335-354.

17. Chrisman, J., J, Chua, H., J., Pearson, W., A., Barnett, T., 2012, Family Involvement, Family Influence, and Family-Centered Non-Economic Goals in Small Firms, Entrepreneurship Theory and Practice, Volume 36, Issue 2, 267-293.

18. Croci, E., Doukas, J., A., and Gonenc, H., 2011, Family Control and Financing Decisions, European Financial Management, Vol 17, no.5, 860-897.

19. Davis, Allen, and Hayes 2010; Is Blood Thicker than Water? A Study of Stewardship Perceptions in Family Business, Entrepreneurship Theory \& Practice 34(6), 1093-1116.

20. Dehmetz, H., and Lehn, K., 1985, The Structure of Corporate Ownership: Causes and Consequences, Journal of Political Economy, Vol 93, 1155-1177.

21. Dreux, 1990, Financing family business: Alternatives to selling out or going public. Family Business Review 3(3):225-243.

22. Feltham, Feltham, and Barnett, 2005, The Dependence of Family Businesses on a Single Decision-Maker, Journal of Small Business Management 43(1), 1-15.

23. Gallo, Tapies, and Cappuyns, 2004, Comparison of Family and Nonfamily Business: Financial Logic and Personal Preferences, Family Business Review 17(4), 303-318.

24. Gomez-Mejía, L., R., Haynes, K., T., Nunez-Nickel, M., Jacobson, K., J., L., and MoyanoFuentes, J., 2007, Socioemotional Wealth and Business Risks in Family-Controlled Firms: Evidence from Spanish Olive Oil Mills, Administrative Science Quarterly, 52(1), 106-137.

25. Fuentes,2007, Socioemotional Wealth and Business Risks in Family-Controlled Firms: Evidence from Spanish Olive Oil Mills, Administrative Science Quarterly 52(1), 106-137.

26. Gudmundson, Tower, and Hartman, 2001, Strategic Implications of Data Gathering Activities: A Comparison between Family and Nonfamily Firms. Paper presented the Annual Meeting of the United States Association of Small Business and Entrepreneurship, Orlando, FL.

27. Harvey and Evans (1995), Forgotten sources of capital for the family-owned business. Family Business Review 8(3):159-175.

28. Hutchinson, 1995, The capital structure and investment decision of the small ownermanaged firm: Some exploratory issues. Small Business Economics 7:231-239.

29. Jensen and Mecklin, 1994, Theory of the Firm: Managerial Behavior, Agency Costs, and Ownership Structure, Journal of Financial Economics 3(4), 305-360.

30. Johnson, E., and Sherraden, M, 2007, From Financial Literacy to Financial Capability Among Youth, Journal of Sociology and Social Welfare, 34, 119-146.

31. Klein, 1999, Family Business in Germany: Significance and Structure, Family Business Review 13(3), 157- 181.

32. Klein, Astrachan, and Smyrnios, 2005, The F-Pec Scale of Family Influence: Construction, Validation, and Further Implication for Theory, Entrepreneurship: Theory and Practice 29(3), 321-333.

33. Koropp C, Grichnik D, and Kellermanns F, 2013, Financial Attitudes in Family Firms: The Moderating Role of Family Commitment, Journal of Small Business Management, 51(1),114-137.

34. Kotkin, 198), Why smart companies are saying no to venture capital. Inc 6:65-75.

35. La Porta, Lopez-de-Silane, and Shleifer, 1999, Corporate Ownership around the World, Journal of Finance 54(2), 471-517.

36. Mahérault, 2004, Is There Any Specific Equity Route for Small and Medium-Sized Family Businesses? The French Experience, Family Business Review 17(3), 221-235. 
37. McConaughy, Matthews, and Fialko, 2001, Founding Family Controlled Firms: Performance, Risk, and Value, Journal of Small Business Management 39(1), 31-49.

38. Matias, F., and Serrasqueiro, Z., 2017, Are there reliable determinant factors of capital structure decisions? Empirical study of SMEs in different regions of Portugal, Research in International Business and Finance, Vol 40, 19-33.

39. Matthews, H., C., Vasudevan, PD, Barton, LS, and Apana, R, 1994, Capital Structure Decision Making in Privately-Held Firms: Beyond the Finance Paradigm, Family Business Review, Vol. 7, No. 4, 349-367.

40. Michaelas, Chittenden, and Poutziouris, 1998, A Model of Capital Structure Decision Making in Small Firms, Journal of Small Business and Enterprise Development 5(3), 246-260.

41. Michiels, A., and Molly, V., 2017, Financing Decision in Family Business: A Review and Suggestions for Developing the Filed, sagepub.com/journals Permissions.nav, pp 369399.

42. Mishra and McConaughy, 1999, Founding Family Control and Capital Structure: The Risk of Loss of Control and the Aversion to Debt, Entrepreneurship: Theory and Practice 23(4), 53-64.

43. Modigliani and Miller, 1963, The Cost of Capital, Corporation Finance and the Theory of Investment, American Economic Review, 48(3), 261-297.

44. Morck and Yeung, 2004, Family Control and the Rent-Seeking Society, Entrepreneurship: Theory and Practice 28(4), 391-409.

45. Myers and Majluf,1984, Corporate Financing and Investment Decisions When Firms Have Information That Investors Do Not Have, Journal of Financial Economics 13(2), 187-221.

46. O'Connor, M., K., and Yaghoubi, M., 2016, The influence of cash flow volatility on capital structure and the use of debt of different maturities, Journal of Corporate Finance, Volume 38, June, 18-36.

47. Pukthuanthong and Walker, 2007, Venture capital in China: A Culture Shock For Western Investors, Management Decision, Vol. 45 Issue: 4, 708-731.

48. Robb, C., A., and Sharpe, D., L., 2009, Effect of Personal Financial Knowledge on College Students' Credit Card Behavior, Journal of Financial Counselling and Planning, Vol 20, Issue 1, 25-43.

49. Romano, CA, Tarnowski, AG, and Smyrnios, XK, 2000 Capital Structure Decision Making: AModel For Family Business, Journal Of Business Venturing, 16, 285-310.

50. Serghiescu, L and LigiaVăidean, V, 2014, Determinant Factors of the Capital Structure of a Firm: an Empirical Analysis, Procedia Economics and Finance, Volume 15, 2014, 1447 1457.

51. Shrivastava and Grant, 1985, Empirically derived models of strategic decision-making processes. Strategic Management Journal 6:97-113.

52. Shleifer, A., and Vishny, RW, 1997, A Survey of Corporate Governance, Journal of Finance, Vol 7, 737-783.

53. Van Auken, Kaufmann, and Herrmann, 2009, Financing Small Technology-Based Companies: The Relationship between Familiarity with Capital and Ability to Price and Negotiate Investment, Journal of Small Business Management 39(3), 240-258.

54. Zahra et al, 2008), Zahra, SA, JC Hayton, DO Neubaum, C. Dibrell, and J. Craig,2008, Culture of Family Commitment and Strategic Flexibility: The Moderating Effect of Stewardship, Entrepreneurship: Theory and Practice 32(6), 1035-1054. 